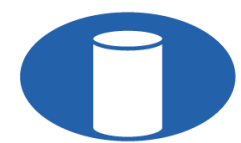

IBRACON Structures and Materials Journal

Revista IBRACON de Estruturas e Materiais

IBRACON

ISSN 1983-4195

ismj.org

ORIGINAL ARTICLE

\title{
A review on the evolution of Portland cement and chemical admixtures in Brazil
}

\section{Uma revisão da evolução do cimento Portland e das misturas químicas no Brasil}

\author{
Juliana Fadini Natalli ${ }^{\mathrm{a}}$ \\ Eduardo Christo Silveira Thomaz ${ }^{\mathrm{b}}$ (D) \\ Júlia Castro Mendes ${ }^{\mathrm{a}}$ (i) \\ Ricardo André Fiorotti Peixoto ${ }^{\mathrm{a}}$
}

${ }^{a}$ Universidade Federal de Ouro Preto - UFOP, Departamento de Engenharia Civil, Ouro Preto, MG, Brasil

${ }^{b}$ Instituto Militar de Engenharia - IME, Seção de Ensino de Engenharia de Fortificação e Construção, Rio de Janeiro, RJ, Brasil

Received 16 December 2020

Accepted 13 April 2021

\begin{abstract}
Over the years, Portland cement concretes have undergone increasing demands for constructability, cost, quality, and environmental impact. These demands were met, mainly, through changes in the cement composition and the introduction of chemical admixtures. In this sense, through a literature review, the authors sought to create a collection of information on the evolution of these materials and their standards from 1937 to 2020 in Brazil . This work is part of a research project that aims to elaborate a dating protocol for Brazilian concretes. From the review conducted, the authors observed that the absence of systematic records in the Brazilian civil construction sector hinders the attempt to create a chronology of the development of concrete in the country. In addition, we concluded that the knowledge of the evolution of Portland cement and chemical admixtures is relevant information that can assist in concrete dating processes. The reliable comparison data, posteriorly combined with microstructural characterisation techniques, may lay the basis for an effective dating methodology.
\end{abstract}

Keywords: Portland cement, chemical admixtures Brazil, cement industry, review, concrete dating.

Resumo: Ao longo dos anos, os concretos de cimento Portland têm sofrido demandas crescentes em termos de construtibilidade, custo, qualidade e impacto ambiental. Essas demandas foram atendidas, principalmente, por meio de mudanças na composição do cimento e introdução de aditivos químicos. Nesse sentido, por meio de uma revisão da literatura, os autores buscaram criar um conjunto de informações sobre a evolução desses materiais e seus padrões de 1937 a 2020 no Brasil. Este trabalho faz parte de um projeto de pesquisa que visa elaborar um protocolo de datação para concretos brasileiros. A partir da revisão realizada, os autores observaram que a ausência de registros sistemáticos no setor da construção civil brasileira dificulta a tentativa de se fazer uma cronologia do desenvolvimento do concreto no país. Além disso, concluiu-se que o conhecimento da evolução do cimento Portland e dos aditivos químicos é uma informação relevante que pode auxiliar em processos de datação de concretos. Os dados de comparação confiáveis, posteriormente combinados com técnicas de caracterização microestrutural, podem servir de base para uma metodologia de datação eficaz.

Palavras-chave: cimento Portland, aditivos químicos no Brasil, indústria cimentícia, revisão, datação de concretos.

How to cite: J. F. Natalli, E. C. S. Thomaz, J. C. Mendes, and R. A. F. Peixoto, "A review on the evolution of Portland cement and chemical admixtures in Brazil,” Rev. IBRACON Estrut. Mater., vol. 14, no. 6, e14603, 2021, https://doi.org/10.1590/S1983-41952021000600003

\section{INTRODUCTION}

The Laboratory of Civil Construction Materials in the Federal University of Ouro Preto recently received the following demand: to date a building that was under legal dispute. The records and documents regarding the exact year 
of construction of this building were inconclusive and/or conflicting. Faced with this challenge, the authors decided to investigate if the dating would be possible through the building materials, more specifically, the concrete.

In addition to the case, knowledge about the age of a concrete structure allows for assessing material durability and determining repair procedures. It can also assist in restoration interventions and historic mapping of buildings. However, despite the relevance for both public and private sectors, no articles or systematic methods for this complex problem were found in the literature.

Carbonation depth has been studied to identify the approximate age of concrete cracks [1]. It is roughly precise as a comparative method (surface already carbonated along the years vs. recently exposed surface of the same concrete) [1]. However, in absolute terms, it has limitations, since the quality of the concrete mixing, pouring, and curing can strongly influence the carbonation depth [2], [3]. Additionally, this phenomenon can be influenced by the technology of chemical admixtures of its time.

The same can be said for chloride ion penetration. Different concrete structures with the same concrete mix proportion and age can have different penetration depths, depending on the curing and exposure conditions [4]. Thus, the age of construction of a concrete structure cannot be accurately associated with its durability parameters.

Regarding dating from the aggregates, most Brazilian aggregates originate from natural crushed rocks [5]. Normally, there are multiple quarries with different geological origins supplying the same city. Additionally, it is known that the mineral characteristics of a rock can vary slightly, even within the same deposit. Therefore, the aggregates' composition is also not a suitable approach for estimating the age of a concrete element.

On the other hand, given that the technological evolution of concrete reflects, above all, the development of Portland cement and the introduction of chemical admixtures to the matrices [6], knowledge on how these materials advance over the years can be useful in dating strategies. A database of the evolution of the use and composition of cement and admixtures in Brazil was not found in the literature and can assist researchers of various fields. In this sense, the present work seeks to create a collection of reliable data on the topic in Brazil. This study represents the initial step on the development of a methodology for dating Brazilian concretes.

\subsection{Review Methodology}

To gather the information on the evolution of these materials and their standards, a narrative literature review was conducted, focusing on the Brazilian construction industry. Since this work seeks to establish a critical historic overview, a systematic approach to the selection of sources was not adopted. The literature covers a wide variety of publication types (e.g., standards, books, reports, conference articles, news) and dates (1937-2020).

The review is divided into two parts. The first covers the development of Portland cement in Brazil, while the second covers the evolution of chemical admixtures in the country. On the Portland cement section, a concise historic background of the first Brazilian plants is presented, followed by the definition of the types currently sold in the market and their current consumption. Subsequently, the authors investigate how the Brazilian Portland cement standards have evolved along the past decades and trace parallels to the American and British ones. To conclude the study on the Portland cement, graphs show the changes in the proportion of clinker components along the last century. Afterwards, the advancements of the use of chemical admixtures and their standards in Brazil are discussed. Finally, the authors present their final remarks with the conclusions drawn from the investigations carried out.

\section{A BRIEF HISTORY OF PORTLAND CEMENT}

In 1824, Joseph Aspdin received a patent for a binder developed by burning limestone and clay. This fine powder received the name Portland cement due to its similarity, in colour and solidifying properties, to the limestone rocks of the British island of Portland. The product created by Aspdin back then had different mineralogy and properties from the Portland cement sold nowadays [7]-[9]. Some modifications performed by this English builder and his son, William Aspdin, in the second half of the 19th century, resulted in a product more similar to the modern material [6].

The well-known constituents of cement are tricalcium silicate $\left(3 \mathrm{CaOSiO}_{2}-\mathrm{C}_{3} \mathrm{~S}\right)$, dicalcium silicate $\left(2 \mathrm{CaOSiO}_{2}-\mathrm{C}_{2} \mathrm{~S}\right)$, tricalcium aluminate $\left(3 \mathrm{CaOAl}_{2} \mathrm{O}_{3}-\mathrm{C}_{3} \mathrm{~A}\right)$ and tetra-calcium aluminoferrite $\left(4 \mathrm{CaOAl}_{2} \mathrm{O}_{3} \mathrm{Fe}_{2} \mathrm{O}_{3}-\right.$ $\left.\mathrm{C}_{4} \mathrm{AF}\right)$. Additionally, other minerals can be formed in minor proportions, such as free lime $(\mathrm{CaO})$, periclase $(\mathrm{MgO})$ and various alkaline sulphates [10], [11]. According to studies carried out by Tennis and Bhatty [12], from 1950 to the present day, the chemical composition of the main constituents of this Portland cement remained essentially unchanged. 
The first record of Portland cement production in Brazil dates from 1888, in a small industrial unit located in the state of São Paulo [13], [14]. This was the first attempt to manufacture hydraulic binders for civil construction purposes in the country [13]. Several isolated cement plants were developed in the following years [14]. However, only in 1933, with the consolidation of the Brazilian Portland Cement Company (Companhia Brasileira de Cimento Portland, in Portuguese), the country achieved a production capacity able to surpass the imports (226 thousand tons at the time), creating prospects for the opening of new plants [13]. In comparison, the first British cement association, the Associated Portland Cement Manufacturers Ltd, was founded in 1900 [15]. In the US, the Association of American Portland Cement Manufacturers (AAPCM) was created in 1902 (and renamed Portland Cement Association, PCA, in 1916) [16].

In 2019, according to the National Union of the Cement Industry (SNIC), the production of this binder reached 42 million tons [17]. In 2017, Brazil was the sixth largest cement producer in the world [18].

\section{TYPES AND COMPOSITION OF BRAZILIAN PORTLAND CEMENT IN BRAZIL OVER THE DECADES}

\subsection{Standardisation in Brazil and comparison with American and British standards}

The first batches of Brazilian-produced Portland cement had no mineral admixtures nor components other than clinker and plaster. This common type is now specified as CP I, where "CP" refers to "Cimento Portland" (Portland cement in Portuguese) and "I" marks the "ordinary" classification. The first Brazilian standard related to Portland cement was published in 1937 [19], approximately 33 years after the first American and British ones [20], [21]. Brazilian type CP I is equivalent to American ASTM type I and British BSI CEM I. The scientific and technological mastery of this product enabled the development of other types of cement in the following years.

One of the first new types was the high early strength Portland cement, specified nowadays in Brazil as CP V (equivalent to ASTM type III and BSI notations "-N" and "-R"). This type must reach a high mechanical resistance in the early ages, obtained from a higher $\mathrm{C}_{3} \mathrm{~S}$ content and by grinding the cement in finer particles, [6], [22]-[24]. In Brazil, its first standardisation dates from 1940.

Aiming to reduce the cost and energy consumption of the manufacturing process [25]-[27], the use of supplementary cementing materials ( $\mathrm{SCMs}$ ) to partially replace the clinker was gradually adopted worldwide. Granulated blast furnace slag was the initial solution, followed by pozzolanic materials [28]. The first cases of adoption of SCMs in the Brazilian cement industry date from 1952, while this practice was already regulated since 1946 in the USA (ASTM C250) and 1923 in the UK [20], [29].

The Portland Blast-Furnace slag cement (now CP III) was the first standardized cement with admixtures in Brazil (1966). It is equivalent to BSI type CEM III and ASTM binary blended cement type IS ("S" for slag), although the Brazilian type currently allows up to $10 \%$ limestone filler (which is not covered in BSI and ASTM binary blended cements).

The Portland-pozzolan cement (now CP IV) was the next blend to get its standard, in 1974. It is equivalent to BSI type CEM IV and ASTM binary blended cement type IP ("P" for pozzolan) but may also include up to 10\% limestone filler. In 1991, the Brazilian Association of Technical Standards (ABNT) published the standard for Portland composite cements (CP II), whose composition is intermediate between ordinary Portland cement (CP I) and Portland cements with blast furnace slag and pozzolanic materials, CP III e CP IV.

The Portland-composite cement can be further divided in CP II - E (clinker + calcium sulphate partially replaced by blast furnace slag and limestone filler), CP II - Z (clinker + calcium sulphate partially replaced by pozzolanic materials and limestone filler) and CP II - F (clinker + calcium sulphate partially replaced by limestone filler). Brazilian types CP II $-\mathrm{E}$ and CP II $-\mathrm{Z}$ are equivalent to ASTM ternary blended cement (IT) but have no equivalent in the BSI standards, which do not include a cement type with high contents of slag + filler or pozzolan + filler. In turn, CP II - F is equivalent to ASTM limestone cement (IL) and, depending on the composition proportion and material quality, can be equivalent to BSI CEM II A-L, A-LL, B-L, or B-LL.

Until 2018, each type of cement had its specific ABNT standard. In that year, the standards were unified in NBR 16697, which, in line with its British and American counterparts, presents all the specifications and requirements for all types of cement. Table 1 summarises the latest Brazilian cement types and their equivalents in the US and UK. Due to its particularities, white cement is not included in the present study. 
Table 1. Summary of current Brazilian cement types and their American and British equivalents [30]-[33].

\begin{tabular}{|c|c|c|c|c|c|c|c|}
\hline \multirow[b]{2}{*}{$\begin{array}{c}\text { Brazilian } \\
\text { ABNT Type }\end{array}$} & \multirow[b]{2}{*}{ Name } & \multicolumn{4}{|c|}{ Composition (range of percentage by mass) } & \multirow[b]{2}{*}{$\begin{array}{l}\text { American } \\
\text { ASTM } \\
\text { equivalent }\end{array}$} & \multirow[b]{2}{*}{$\begin{array}{l}\text { British BSI } \\
\text { equivalent }\end{array}$} \\
\hline & & $\begin{array}{c}\text { Clinker + } \\
\text { calcium } \\
\text { sulphate }\end{array}$ & $\begin{array}{l}\text { Granulated blast } \\
\text { furnace slag }\end{array}$ & $\begin{array}{c}\text { pozzolanic } \\
\text { materials }\end{array}$ & $\begin{array}{l}\text { limestone } \\
\text { filler }\end{array}$ & & \\
\hline CP I & $\begin{array}{c}\text { Ordinary Portland } \\
\text { cement }\end{array}$ & $95-100$ & & $0-5$ & & Type I & CEM I \\
\hline CP I-S & $\begin{array}{l}\text { Ordinary Portland } \\
\text { cement with } \\
\text { admixtures }\end{array}$ & $90-94$ & 0 & 0 & $6-10$ & Type I & $\begin{array}{l}\text { CEM II A-L or } \\
\text { A-LL }{ }^{1}\end{array}$ \\
\hline CP II-E & $\begin{array}{l}\text { Portland- } \\
\text { composite cement } \\
\text { with blast furnace } \\
\text { slag }\end{array}$ & $51-94$ & $6-34$ & 0 & $0-15$ & Type IT $(\operatorname{L} \alpha)(\mathrm{S} \beta)^{2}$ & - \\
\hline CP II-Z & $\begin{array}{l}\text { Portland- } \\
\text { composite cement } \\
\text { with pozzolanic } \\
\text { materials }\end{array}$ & $71-94$ & 0 & $6-14$ & $0-15$ & $\underset{2}{\text { Type IT(L } \alpha)(\mathrm{P} \beta)}$ & - \\
\hline CP II-F & $\begin{array}{l}\text { Portland- } \\
\text { composite cement } \\
\text { with limestone } \\
\text { filler }\end{array}$ & $75-89$ & 0 & 0 & $11-25$ & Type $\operatorname{IL}(\alpha)^{2}$ & $\begin{array}{l}\text { CEM II A-L, } \\
\text { A-LL, B-L, or } \\
\text { B-LL }\end{array}$ \\
\hline CP III & $\begin{array}{l}\text { Portland blast- } \\
\text { furnace slag } \\
\text { cement }\end{array}$ & $25-65$ & $35-75$ & 0 & $0-10$ & Type $\operatorname{IS}(\alpha)^{2,3}$ & CEM III A or $\mathrm{B}^{3}$ \\
\hline CP IV & $\begin{array}{c}\text { Portland-pozzolan } \\
\text { cement }\end{array}$ & $45-85$ & 0 & $15-50$ & $0-10$ & Type $\operatorname{IP}(\alpha)^{2,3}$ & CEM IV A or $\mathrm{B}^{3}$ \\
\hline $\mathrm{CP} \mathrm{V}$ & $\begin{array}{l}\text { High early strength } \\
\text { Portland cement }\end{array}$ & $90-100$ & 0 & 0 & $0-10$ & Type III & $\begin{array}{l}\text { Notation "-N" or } \\
\text { "-R" to the other } \\
\text { types }\end{array}$ \\
\hline
\end{tabular}

${ }^{1}$ Brazilian CP I-S may contain 6-10\% limestone filler, while British CEM II/A may contain 6-20\%. Therefore, they are only equivalent when the cement comprises up to $10 \%$ limestone filler. ${ }^{2}$ Where $\alpha$ and $\beta$ are the replacement rate of the material. E.g. a) $20 \%$ slag (S) and $10 \%$ limestone filler (L) $=$ Type IT(S20)(L10); b) $40 \%$ pozzolan $(\mathrm{P})=\mathrm{IP}(40) .{ }^{3}$ Brazilian standards allow up to $10 \%$ limestone filler to binary blends CP III and CP IV since 2018 , whereas their American and British counterparts do not. An American cement with both limestone filler and slag or pozzolan would be identified as a ternary blend. British BSI standard does allow up to 5\% "minor additional constituents" but does not label them as limestone filler.

The American cement classifications are based on the intended use or resulting property (e.g., Type II - when moderate sulphate resistance is desired, or Type IV - when a low heat of hydration is desired). On the other hand, the Brazilian and British naming systems mostly consider the type and content of mineral admixtures. The current Brazilian standard, NBR 16697, allows the application of the suffixes "RS" for sulphate resistance and "BC" for low heat of hydration to any cement type, given that it fulfils the prescribed specifications.

Both American and British standards require some form of identification of how much mineral admixture is added to the cement. The American ASTM prescribes a straightforward approach: the percentage of each admixture must be clearly stated (e.g. IT(S20)(L10) or IP(40)). British standards have different ratings for different replacement percentages. For example, blast furnace cement (CEM III) can be classified as "A" if 36-65\% of its clinker + calcium sulphate is replaced by blast furnace slag; "B", for $66-80 \%$; and " $\mathrm{C}$ " for $81-95 \%$. Brazilian cement manufacturers are not required to display this information; they only use it to classify their cement in the broad ranges mentioned in Table 1.

Both ASTM and BSI allow blends with both slag and pozzolans, currently not allowed by Brazilian ABNT. Also, the British standard provides specifications on the type of pozzolanic addition, and the quality of the carbonaceous material used. The Brazilian standard does not require the manufacturer to specify whether only one or more than one type of pozzolan is used. There is also no mention of whether this is allowed.

While the British BSI standard allows any type of cement to have high initial strength, Brazilian ABNT and American ASTM standards restrict this characteristic to a specific type of cement. BSI also brings 2 classifications for high initial strength cement (according to performance limits), in addition to 1 classification for low initial strength cement, which does not happen for Brazilian and American cement types.

Finally, the American ASTM standards have the notation "-A" to indicate air-entrained cement. Since Brazil is a tropical country where temperatures rarely fall below $0^{\circ} \mathrm{C}$, the concretes are not commonly required to ensure freezing and thawing durability. 
Nowadays, all Brazilian types of cement (except for High Early Strength) must present one out of three strength classes: 25,32 or 40 [30]. These values represent the minimum 28-days compressive strength (in $\mathrm{MPa}$ ) required from a standard 1:3 mortar cast in $\phi 5 \times 10 \mathrm{~cm}$ cylindrical specimens. High Early Strength Portland cement $(\mathrm{CP} V)$ must reach $14 \mathrm{MPa}$ in 24 hours and $34 \mathrm{MPa}$ in 7 days. Its strength class is called "ARI", standing for "Alta Resistência Inicial" (High Early Strength).

\subsection{Portland cement consumption in Brazil}

Figure 1 presents the evolution of consumption of Brazilian Portland cement types according to data from the National Union of the Cement Industry (SNIC), presented at statistical yearbooks published by the Brazilian Institute of Geography and Statistics (IBGE) [34].

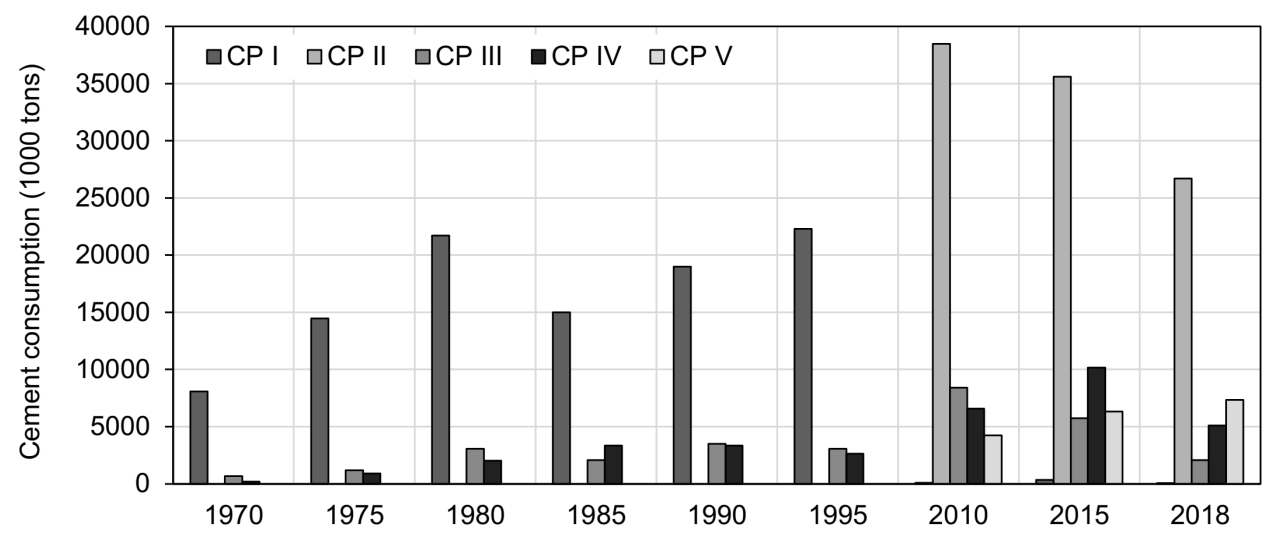

Figure 1. Brazilian consumption of Portland cement, by type. Note: the yearbooks of the 70s, $80 \mathrm{~s}$ and 90 s do not present values for CP V consumption, and there was no specification on the consumption of Portland cement in the years 2000 and 2005.

Ordinary Portland cement (CP I) was the most adopted in Brazilian constructions until 1995. From 1996 onwards, Portland-composite cement (CP II) takes its place as the favourite in the usual construction applications. The replacement of CP I by CP II is probably linked to the reduction of costs related to the use of SCMs, as will be later discussed. Nowadays, the commercial production of $\mathrm{CP}$ I is restricted to cement companies far from thermoelectric and steel industries, such as those in the Northern region of Brazil.

The graph also shows a significant increase in cement consumption (for all types) in the last decade, followed by a slight decrease in 2018 due to the economic recession in Brazil. CP III and CP IV have also been gaining space in the Brazilian market, attributed to the greater use of these types in concrete elements of large volume (such as dams and foundations), and in those that require greater durability. Finally, the increase in CP V consumption stands out in the past few years, probably related to the advance of precast concrete structures and the requirement for quicker formwork removal times, associated with the industrialisation of civil construction in the country.

\subsection{Types of Portland cement in Brazil}

\subsubsection{Ordinary Portland cement (CP I and CP I-S)}

The first cement type produced and sold in Brazil was the ordinary Portland cement (originally CP, now CP I), without any components other than clinker and calcium sulphate [28], [35]. Table 2 shows the evolution of the standardisation of CP I in Brazil. It is noteworthy that, from 1977 onwards, the addition of small amounts of SCMs to this type of cement was allowed, probably due to the cost, performance and environmental advantages achieved in $\mathrm{CP}$ III and CP IV, as will be seen in the next sections. In 1988, the CP I was broken down in three types (CPS, CPE, and CPZ), according to the mineral admixture added to it. In 1991 a new subtype for low levels of admixtures was established, the "ordinary Portland cement with admixture", CP I-S, and CP I returned as the type without any. 
Table 2. Evolution of standardisation of the ordinary Portland cement (CP I and CP I-S) in Brazil, in terms of maximum clinker + calcium sulphate replacement in mass.

\begin{tabular}{|c|c|c|c|c|}
\hline Standard & Year & $\begin{array}{l}\text { Allowed content of mineral admixtures } \\
\text { for CP I }\end{array}$ & $\begin{array}{l}\text { Allowed content of mineral admixtures } \\
\text { for CP I-S }\end{array}$ & $\begin{array}{l}\text { Strength } \\
\text { classes }\end{array}$ \\
\hline $\begin{array}{l}\text { EB-1 (originally) } \\
\text { NBR } 5732\end{array}$ & 1937 & $0 \%$ & - & 25 \\
\hline $\begin{array}{l}\text { EB-1 (originally) } \\
\quad \text { NBR } 5732\end{array}$ & 1973 & $0 \%$ & - & 253240 \\
\hline \multirow{2}{*}{ NBR 5732} & \multirow{2}{*}{1977} & 0 to $10 \%$ blast furnace slag & \multirow{2}{*}{-} & 2532 \\
\hline & & $0 \%$ & & 40 \\
\hline \multirow{3}{*}{ NBR 5732} & \multirow{3}{*}{1988} & 0 to $5 \%$ limestone filler (CPS) & \multirow{3}{*}{-} & \multirow{3}{*}{253240} \\
\hline & & $0 \%$ to $10 \%$ blast furnace slag $(\mathrm{CPE})$ & & \\
\hline & & $0 \%$ to $10 \%$ pozzolanic materials $(\mathrm{CPZ})$ & & \\
\hline NBR 5732 & 1991 & $0 \%$ & $\begin{array}{c}0 \% \text { to } 5 \% \text { blast furnace slag or pozzolanic } \\
\text { materials or limestone filler }\end{array}$ & 253240 \\
\hline NBR 16697 & 2018 & $\begin{array}{c}0 \% \text { to } 5 \% \text { blast furnace slag or pozzolanic } \\
\text { materials or limestone filler }\end{array}$ & 6 to $10 \%$ limestone filler & 253240 \\
\hline
\end{tabular}

\subsubsection{Portland Blast-Furnace slag cement (CP III)}

Granulated blast furnace slag, a by-product of the conversion of iron ore into pig iron, is comprised mainly by $\mathrm{CaO}$, $\mathrm{SiO}_{2}$ and $\mathrm{Al}_{2} \mathrm{O}_{3}$ [36], and consists of a vitreous material with cementing properties [37], [38].

In Brazil, the addition of blast furnace slag to Portland cement began in 1952, with the Tupi company, in the city of Volta Redonda (state of Rio de Janeiro), using the residues from the National Steel Company (Companhia Siderúrgica Nacional - CSN) [39]. In 2017, Brazil was the ninth-largest steel producer in the world, manufacturing 34.4 million tons of the metal, and generating 8.8 million tons of blast furnace slag in the process [40]. Table 3 shows the evolution of the standardisation of CP III in Brazil.

Table 3. Evolution of standardisation of the Portland Blast-Furnace slag cement (CP III) in Brazil, in terms of maximum clinker + calcium sulphate replacement in mass.

\begin{tabular}{|c|c|c|c|}
\hline Standard & Year & $\begin{array}{l}\text { Allowed content of mineral admixtures } \\
\text { for CP III }\end{array}$ & Strength classes \\
\hline EB-208 (originally) & \multirow{2}{*}{1966} & \multirow{2}{*}{$25 \%$ to $65 \%$ blast furnace slag } & \multirow{2}{*}{25} \\
\hline NBR 5735 & & & \\
\hline NBR 5735 & 1974 & $25 \%$ to $65 \%$ blast furnace slag & 2532 \\
\hline \multirow{2}{*}{ NBR 5735} & \multirow{2}{*}{1987} & $35 \%$ to $70 \%$ blast furnace slag & \multirow{2}{*}{253240} \\
\hline & & $0 \%$ to $5 \%$ limestone filler & \\
\hline \multirow{2}{*}{ NBR 5735} & \multirow{2}{*}{1991} & $35 \%$ to $70 \%$ blast furnace slag & \multirow{2}{*}{253240} \\
\hline & & $0 \%$ to $5 \%$ limestone filler & \\
\hline \multirow{2}{*}{ NBR 16697} & \multirow{2}{*}{2018} & $35 \%$ to $75 \%$ blast furnace slag & \multirow{2}{*}{253240} \\
\hline & & $0 \%$ to $10 \%$ limestone filler & \\
\hline
\end{tabular}

In the 1960s, there was only one strength class for Portland blast furnace cement, 25. Classes 32 and 40 came in the $70 \mathrm{~s}$ and $80 \mathrm{~s}$, respectively. Technological advances in the cement manufacturing process, such as the increase of grain fineness and changes in $\mathrm{C}_{3} \mathrm{~S}$ content, led to greater mechanical strength [22]-[24], [6].

The increasing trend in the replacement of clinker + calcium sulphate by blast furnace slag continued from the 1980s onwards. Several factors are favourable to this adoption. First, the increased use of SCMs promotes a reduction in $\mathrm{CO}_{2}$ emissions, energy costs and consumption of natural resources. Secondly, the incorporation of slag into cement production also contributes to a more suitable destination for these residues. These scenarios also reduce the costs and environmental impacts of both steel and cement companies. Finally, there are major technological advantages in increasing the replacement of clinker by SCMs in cement-based composites, such as the reduction of the heat of hydration, lower permeability, and greater durability [41], [36], [38].

With all these advantages, coupled with the increase in cement consumption in recent years, in 2009 the steelmaker CSN inaugurated its own cement plant [42]. With the supply of blast furnace slag reduced, as the main supplier in the 
Southeastern Region now consumes most of its production, some Brazilian cement companies started to import their slag from foreign steelmakers. Others began to invest in pozzolanic materials [14].

\subsubsection{Portland-pozzolan cement (CP IV)}

Pozzolans are SCMs that by themselves possess little or no cementing capacity, but finely divided and in presence of moisture chemically react with calcium hydroxide $\left(\mathrm{Ca}(\mathrm{OH})_{2}\right.$ or $\left.\mathrm{CH}\right)$, forming calcium silicate hydrates $(\mathrm{C}-\mathrm{S}-\mathrm{H})$ [11]. The reaction between the pozzolan and $\mathrm{CH}$ is called pozzolanic activity, and the resulting C-S-H increases the strength and decreases the permeability of the matrix.

In Brazil, the addition of pozzolanic materials to Portland cement began only in 1969 by Indústrias Reunidas Francisco Matarazzo, with the use of fly ash from the Charqueadas thermoelectric plant [39]. Table 4 shows the evolution of the standardisation of CP IV in Brazil. There has been an increase in the maximum allowed content of pozzolanic additions to cement over the years. This increase is also related to the environmental, economic, and technological factors previously mentioned for the blast furnace slag.

Table 4. Evolution of standardisation of Portland-pozzolan cement (CP IV) in Brazil, in terms of maximum clinker + calcium sulphate replacement in mass.

\begin{tabular}{|c|c|c|c|}
\hline Standard & Year & Allowed content of mineral admixtures for CP IV & Strength classes \\
\hline EB-758 (originally) & \multirow{2}{*}{1974} & $10 \%$ to $40 \%$ pozzolanic materials & 25 \\
\hline NBR 5735 (later) & & $10 \%$ to $30 \%$ pozzolanic materials & 32 \\
\hline NBR 5736 & 1986 & $15 \%$ to $40 \%$ pozzolanic materials & 2532 \\
\hline \multirow{2}{*}{ NBR 5736} & \multirow{2}{*}{1991} & $15 \%$ to $50 \%$ pozzolanic materials & \multirow{2}{*}{2532} \\
\hline & & $0 \%$ to $5 \%$ limestone filler & \\
\hline \multirow{2}{*}{ NBR 16697} & \multirow{2}{*}{2018} & $15 \%$ to $50 \%$ pozzolanic materials & \multirow{2}{*}{253240} \\
\hline & & $0 \%$ to $10 \%$ limestone filler & \\
\hline
\end{tabular}

The pozzolanic materials most used by the cement industries are silica fume, fly ash, volcanic ash, rice husk ash, and metakaolin [43]-[45]. In Brazil, given the size of the country, the type of pozzolana adopted varies with the availability of each region. In the Southern Region, for example, fly ash is widely used, obtained from the thermoelectric plants of the area. In the Northeastern region, calcined clays are the most common pozzolans adopted [28].

\subsubsection{Portland-composite cement (CP II-E, CP-II Z and CP II-F)}

Composite cement was the last one to be standardised. The three types of composite cement (CP II-E, CP II-Z and CP II-F) may have limestone fillers, with CP II-E and CP II-Z also presenting intermediate levels of blast furnace slag and pozzolanic materials, respectively. Table 5 shows the evolution of the standardisation of CP II in Brazil.

Table 5. Evolution of standardisation of Portland-composite cement (CP II) in Brazil, in terms of maximum clinker + calcium sulphate replacement in mass.

\begin{tabular}{|c|c|c|c|c|c|}
\hline Standard & Year & $\begin{array}{l}\text { Allowed content of } \\
\text { mineral admixtures for } \\
\text { CP II-E }\end{array}$ & $\begin{array}{l}\text { Allowed content of } \\
\text { mineral admixtures for } \\
\text { CP II-Z }\end{array}$ & $\begin{array}{l}\text { Allowed content of } \\
\text { mineral admixtures for } \\
\text { CP II-F }\end{array}$ & $\begin{array}{l}\text { Strength } \\
\text { classes }\end{array}$ \\
\hline \multirow[t]{2}{*}{ NBR 11578} & \multirow[t]{2}{*}{1991} & $\begin{array}{c}6 \% \text { to } 34 \% \text { blast furnace } \\
\text { slag }\end{array}$ & $\begin{array}{c}6 \% \text { to } 14 \% \text { pozzolanic } \\
\text { materials }\end{array}$ & \multirow[t]{2}{*}{$6 \%$ a $10 \%$ limestone filler } & \multirow[t]{2}{*}{253240} \\
\hline & & filler0\% to $10 \%$ limestone & limestone $0 \%$ to $10 \%$ filler & & \\
\hline \multirow[t]{2}{*}{ NBR 16697} & \multirow[t]{2}{*}{2018} & $\begin{array}{c}6 \% \text { to } 34 \% \text { blast furnace } \\
\text { slag }\end{array}$ & $\begin{array}{c}6 \% \text { to } 14 \% \text { pozzolanic } \\
\text { materials }\end{array}$ & \multirow[t]{2}{*}{$11 \%$ a $25 \%$ limestone filler } & \multirow[t]{2}{*}{253240} \\
\hline & & $0 \%$ to $15 \%$ limestone filler & $0 \%$ to $15 \%$ limestone filler & & \\
\hline
\end{tabular}

Note that Brazilian standards only allow the use of "carbonate materials" as fillers, not referring to other types of inert minerals. The limestone filler is obtained from ground limestone rocks. Up to certain limits, this mineral admixture is known to increase concrete workability in the fresh state, as the fine particles act as a lubricant [46], [47]. In the hardened state, the fillers promote filling of voids and dispersion of grains [48], leading to enhanced mechanical strength 
and lower porosity [46], [47]. Due to these technical advantages and its relatively low cost, the maximum allowed addition of limestone filler in Brazilian cement has been increased over the decades.

\subsubsection{High Early Strength Portland Cement (CP V)}

High Early Strength Portland cement (CP V) was first regulated in 1940, only 3 years after CP I. The mastery of Portland cement composition, grinding processes and hydration reactions enabled the development of CP I to a binder capable of producing matrices with high resistance already in early ages. Although its standardisation is relatively old, only in the past decade the CP V has gained space in the Brazilian market, due to the growth of the precast industries, the introduction of cast-in-place concrete wall systems, and the pressure for increasingly early removal of concrete formworks in conventional structures [28]. Table 6 shows the evolution of the standardisation of CP V in Brazil.

Table 6. Evolution of standardisation of the High Early Strength Portland cement (CP V) in Brazil, in terms of maximum clinker + calcium sulphate replacement in mass.

\begin{tabular}{|c|c|c|c|c|c|}
\hline \multirow{2}{*}{ Standard } & \multirow{2}{*}{ Year } & \multirow{2}{*}{$\begin{array}{l}\text { Allowed content of mineral } \\
\text { admixtures for } \mathrm{CP} \mathrm{V}\end{array}$} & \multicolumn{3}{|c|}{ Minimum strength (MPa) } \\
\hline & & & 1 day & 3 days & 7 days \\
\hline EB-2 (originally) & \multirow{2}{*}{1940} & \multirow{2}{*}{$0 \%$ to $1 \%$ of any material } & \multirow{2}{*}{11} & \multirow{2}{*}{22} & \multirow{2}{*}{31} \\
\hline NBR 5733 (later) & & & & & \\
\hline NBR 5733 & 1974 & $0 \%$ & 11 & 22 & 31 \\
\hline NBR 5733 & 1991 & 0 to $5 \%$ limestone filler & 14 & 24 & 34 \\
\hline NBR 16697 & 2018 & 0 to $10 \%$ limestone filler & 14 & 24 & 34 \\
\hline
\end{tabular}

As of the 1991 regulations, an increase in the mechanical strength is required at all ages. This demand is obtained through an enhanced grinding process and an increase in the clinker's $\mathrm{C}_{3} \mathrm{~S}$ content, which accelerate the hydration reactions at early ages [2]-[5]. It is also noticeable that, related to the reduction in costs and environmental impacts, the 2018 version allows a greater amount of limestone filler addition to this type of cement.

\subsection{Evolution of clinker components}

Since the development of Portland cement, its most demanded properties are the speed and intensity of mechanical strength gain [6]. To this purpose, the proportion of cement constituents and the fineness of the grains have been changing over the years [2]-[5].

This development was made possible thanks to studies on cement chemistry and advances in micro and nanometric characterisation techniques [7]-[9]. These analyses allowed, above all, the better understanding of the hydration mechanisms of the Portland cement components [8], [10]-[12] and their interactions with other materials [13]-[15]. The improvement in the quality of the cement was also possible due to the evolution of kiln designs, which ensured a greater control of production and an increase in clinker uniformity [16], [17].

Figure 2 shows trends in the levels of constituents of Portland cements produced worldwide over time. Brazilian cement technology followed the same trends. The graphs were constructed from a series of data collected in books and scientific articles, shown in the Appendix.

The increase in the average $\mathrm{C}_{3} \mathrm{~S}$ content by about $100 \%$ and the reduction in the average $\mathrm{C}_{2} \mathrm{~S}$ content by approximately $66 \%$ are related to rapid strength gain of the concretes, a characteristic increasingly demanded by the construction industry [3], [4], [8]. Although the C-S-H produced by the hydration of $\mathrm{C}_{3} \mathrm{~S}$ and $\mathrm{C}_{2} \mathrm{~S}$ have similar structure, the hydration of $\mathrm{C}_{3} \mathrm{~S}$ occurs much earlier, contributing to almost half of the mechanical strength at 28 days [8].

These results agree with the literature. Gonnerman and Lerch [2] studied concrete samples collected between 1904 and 1950 and observed an increase in the specific surface of the grains and the $C_{3} S$ content. More recently, Tennis and Bhatty [18] analysed cement samples from 1950 to 2004 and reached the same conclusions.

One of the consequences of the increase in the $\mathrm{C}_{3} \mathrm{~S}$ proportion and grain fineness is an increase in the heat released during hydration reactions. In this sense, the reduction of the average $\mathrm{C}_{3} \mathrm{~A}$ content by about $31 \%$ can be justified by the search for lower heat release, since $\mathrm{C}_{3} \mathrm{~A}$ is one of the components that most contribute to the exothermic nature of the hydration process [8], [19]. The only main constituent that remained roughly unaltered over the years was the $\mathrm{C}_{4} \mathrm{AF}$ phase, possibly due to its low impact on the mechanical and rheological properties and in the hydration kinetics. 

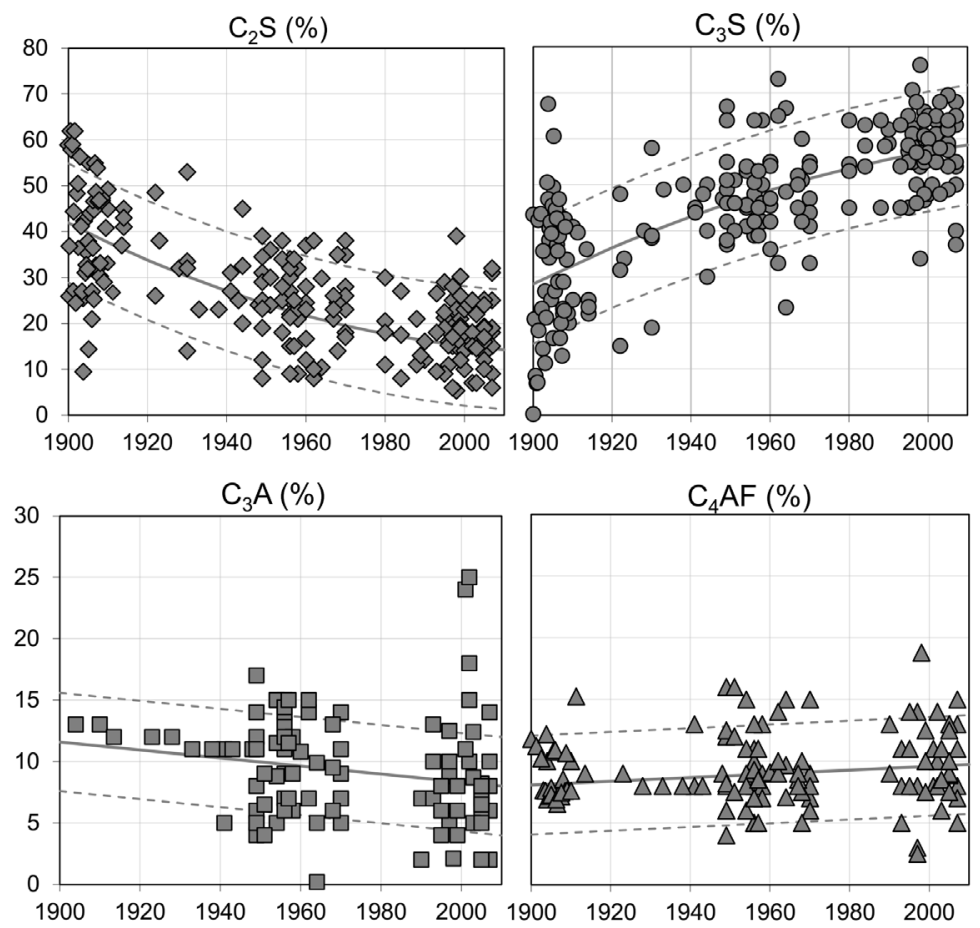

Figure 2. Variation in the proportion of the main components of Portland cements over the years in Brazil and worldwide.

\section{TYPES OF CHEMICAL ADMIXTURES IN BRAZIL OVER THE DECADES}

\subsection{Use of admixtures in Brazilian concretes}

The advances in concrete performance were promoted not only by modifications on the proportion of cement constituents and the increase in grain fineness, but also by the improvement of construction technologies and the emergence of chemical admixtures [5]. There are today over 20 commercial types of admixtures, which are capable of interfering with hydration kinetics, the amount of hydration products formed and the intermolecular attraction forces between cement grains [20].

Mehta and Monteiro [11] indicate that about 80 to $90 \%$ of the concrete produced in developed countries has at least one chemical admixture. In Brazil, there are no data on the use of admixtures, and there is no national syndicate or association of admixture manufacturers. It is believed that the percentage of concretes with admixtures is significantly lower, due to the predominance of self-built homes in the country [21], and the lack of technological control of concrete production in most construction sites [22]. However, in general lines, the concrete practices in the country have usually followed international trends.

Mehta and Burrows [24] point out that the industrial growth from 1950 onwards boosted the development of pumped concretes and the consolidation of immersion (or needle) vibrators. According to the authors, these factors triggered the need for more fluid concretes, which, before the advent of plasticizer admixtures in the 1960s, were only attained by increasing the water content.

The first plasticizer admixtures, developed in Japan in the 1960s [23], were introduced to the Brazilian market in the same decade [24]. Initially, they were mostly adopted by consumers with a high-level technical background, such as concrete plants.

In that same decade, the first superplasticizers based on sulfonated naphthalene-formaldehyde condensate were being formulated [24]. The dissemination of these admixtures reduced the water/cement ratio and improved the workability of fresh concrete. Due to these factors, these products have led to more resistant and less permeable concretes worldwide [25], [26]. In Brazil, these mixtures were introduced only in the mid-1970s [27].

This successful use of superplasticizers, coupled with labour shortages and construction time savings, encouraged the development of self-compacting concretes (SCC) in the 1980s in Japan [28]. According to Faria [49], SCC arrived in Brazil in the 1990s. The increase in productivity allowed this type of material to be used in the Brazilian precast 
concrete industries [30]. There are no official data on the subject, but Costa and Cabral [31] state that the SCC in vertical constructions is still little used in Brazil, mainly due to the higher initial cost of the material.

The 1980s were also marked by the development of polycarboxylate-based superplasticizer admixtures by Japanese chemical industries [32], [33]. This new generation, which was popularized in Brazil and worldwide in the 1990s, promoted the development of high- and ultra-high-strength concretes [24].

There are no reports of when the set retarding admixtures started to be commercialised in the Brazilian market, however, it is assumed that their use has intensified since the consolidation of concrete plants in the country in the 1960s [34]. This type of admixture is especially important in hot climates, allowing a longer period for concrete mixing and pouring [24].

Ultimately, no records were found in the Brazilian literature regarding the beginning of the adoption of the other types of admixtures in the country. There was also no data on their production volume and when the first chemical industries were established. Records of when these admixtures were first introduced in the Brazilian concretes can lead to valuable clues as to the age of a concrete element. By identifying the chemical component of the admixture in the cement matrix, the age of the structure can be traced over a narrow range of years. The authors have ongoing initiatives seeking to recognize the type of admixture used in samples taken from hardened concrete.

\subsection{Standardisation in Brazil and comparison with American and British standards}

In Brazil, chemical admixtures for Portland cement concrete are currently specified by NBR 11768, whose first version was published in 1987 (originally EB-1763). In comparison, the first standards for admixtures in the US were published in 1977 (ASTM C 260) and 1979 (ASTM C 494); and, in the UK, 1974 (BS 5075-1, now BS EN 934-2).

NBR 11768 prescribes the required conditions related to homogeneity, colour, specific gravity, $\mathrm{pH}$, solid residues content, and chlorides content; and determines the tests to be carried out on the concretes with admixtures. It also specifies that the mass of admixtures added during the concrete mixing should not exceed 5\% in relation to the mass of Portland cement. The standard currently allows this amount to be exceeded in some specific applications, such as admixtures for shotcrete and shrinkage compensators.

In Brazil, there are no standards for admixtures for cement-based composites other than concrete (e.g., mortars and grouts). Table 7 shows the different types of standardised admixtures in the country and their equivalents in the US and UK.

Table 7. Types of chemical admixtures standardized in Brazil according to NBR 11768, and their American and British equivalents [35]-[38].

\begin{tabular}{|c|c|c|c|c|}
\hline $\begin{array}{l}\text { Brazilian } \\
\text { ABNT Type }\end{array}$ & Chemical admixture & Characteristics & $\begin{array}{c}\text { American ASTM } \\
\text { Equivalent }\end{array}$ & $\begin{array}{l}\text { British BSI } \\
\text { Equivalent }\end{array}$ \\
\hline $\mathrm{PN}$ & Water-reducing & $\begin{array}{c}\text { First-generation plasticizer, based on } \\
\text { lignosulfonates. }\end{array}$ & $\mathrm{A}^{1}$ & $\begin{array}{l}\text { Water reducing/ } \\
\text { plasticizing }^{1}\end{array}$ \\
\hline SP-I N & High-range water-reducing Type I & $\begin{array}{l}\text { Second-generation superplasticizer, based on } \\
\text { condensates of formaldehyde sulfonates. }\end{array}$ & \multirow{2}{*}{$\mathrm{F}^{1}$} & \multirow{2}{*}{$\begin{array}{l}\text { High range water } \\
\text { reducing/ } \\
\text { superplasticizing }^{1}\end{array}$} \\
\hline SP-II N & $\begin{array}{c}\text { High-range water-reducing } \\
\text { Tipo II }\end{array}$ & $\begin{array}{l}\text { Third generation superplasticizer, based on } \\
\text { polycarboxylate. }\end{array}$ & & \\
\hline IA & Air-entraining & $\begin{array}{l}\text { Incorporates uniformly distributed micropores of } \\
\text { air during the mixing of the concrete, which } \\
\text { remain in the hardened state. }\end{array}$ & Air-Entraining ${ }^{2}$ & Air entraining \\
\hline $\mathrm{AP}$ & Set Accelerating & $\begin{array}{l}\text { Decreases the transition time from the plastic to } \\
\text { the rigid state of the concrete. }\end{array}$ & $\mathrm{C}$ & Set accelerating \\
\hline AR & Strength accelerator & $\begin{array}{c}\text { Increases the rate of development of the initial } \\
\text { strength of the concrete, with or without } \\
\text { affecting setting time. }\end{array}$ & -3 & $\begin{array}{l}\text { Hardening } \\
\text { accelerating }\end{array}$ \\
\hline PP & Set Retarding & $\begin{array}{l}\text { Increases the transition time from the plastic to } \\
\text { the rigid state of the concrete. }\end{array}$ & $\mathrm{B}$ & Set retarding \\
\hline PR & Water-reducing and Set Retarding & $\begin{array}{c}\text { Combines the effects of a plasticizer (main } \\
\text { function) and the effects of a retarder (secondary } \\
\text { function) }\end{array}$ & $\mathrm{D}^{1}$ & $\begin{array}{l}\text { Set retarding/ } \\
\text { water reducing/ } \\
\text { plasticizing }\end{array}$ \\
\hline $\begin{array}{l}\text { SP-I R or } \\
\text { SP-II R }\end{array}$ & $\begin{array}{l}\text { High-range water-reducing and } \\
\text { Set Retarding }\end{array}$ & $\begin{array}{l}\text { Combines the effects of type I or II } \\
\text { superplasticizer (main function) and the effects } \\
\text { of a retarder (secondary function). }\end{array}$ & $\mathrm{G}^{1}$ & $\begin{array}{l}\text { Set retarding/ high } \\
\text { range water } \\
\text { reducing/ } \\
\text { superplasticizing }\end{array}$ \\
\hline
\end{tabular}


Table 7. Continued...

\begin{tabular}{|c|c|c|c|c|}
\hline $\begin{array}{l}\text { Brazilian } \\
\text { ABNT Type }\end{array}$ & Chemical admixture & Characteristics & $\begin{array}{l}\text { American ASTM } \\
\text { Equivalent }\end{array}$ & $\begin{array}{l}\text { British BSI } \\
\text { Equivalent }\end{array}$ \\
\hline $\mathrm{PA}$ & $\begin{array}{l}\text { Water-reducing and Set } \\
\text { Accelerating }\end{array}$ & $\begin{array}{l}\text { Combines the effects of a plasticizer (main } \\
\text { function) and the effects of an accelerator } \\
\text { (secondary function) }\end{array}$ & $\mathrm{E}^{1}$ & $\begin{array}{l}\text { Set accelerating/ } \\
\text { water reducing/ } \\
\text { plasticizing }^{1}\end{array}$ \\
\hline $\begin{array}{l}\text { SP-I A or SP-II } \\
\text { A }\end{array}$ & $\begin{array}{l}\text { High-range water-reducing and } \\
\text { Set Accelerating }\end{array}$ & $\begin{array}{l}\text { Combines the effects of type I or II } \\
\text { superplasticizer (main function) and the effects } \\
\text { of an accelerator (secondary function). }\end{array}$ & - & - \\
\hline MV-RT & Water retainer viscosity modifier & $\begin{array}{l}\text { Retains water inside the concrete reducing the } \\
\text { bleeding effect }\end{array}$ & $--^{3}$ & Water retaining \\
\hline MV-AS & Anti-washout viscosity modifier & $\begin{array}{l}\text { Reduces segregation of fluid or self-compacting } \\
\text { concretes and allows the pouring of submerged } \\
\text { concretes }\end{array}$ & -3 & $\begin{array}{l}\text { Viscosity } \\
\text { modifying }\end{array}$ \\
\hline
\end{tabular}

${ }^{1}$ Brazilian standard differentiates Water-reducing from High-range water-reducing admixtures according to the chemical composition. ASTM and BSI prescribe that the former should be able to reduce at least $5 \%$ of mixing water, and the latter at least $12 \% .{ }^{2}$ ASTM C494 does not have a specific letter/classification for Airentraining admixtures, which are separately regulated by ASTM C260. ${ }^{3}$ While ASTM C494 covers admixture types A to G, it does present provisions for a Type S, adopted when specific performance characteristics are required. ${ }^{4}$ Brazilian standard specifies the Anti-washout viscosity modifier for self-compacting and submerged concretes, while BSI only mentions that it is "incorporated in concrete to limit segregation by improving cohesion".

Although the first Brazilian standards on chemical admixtures for concrete date from the late 1980s, there were reports of the use of plasticizers and set retarders decades before them, as seen in the previous section. The first standards launched in Brazil were EB-1763 (in 1987), with the specifications and requirements for various types, and EB-1842 (in 1987), specific for superplasticizers. In 1992, these standards were merged into NBR 11768.

The standards prior to 2011 did not establish maximum limits for the content of admixtures in concrete. Furthermore, they did not prescribe the specific requirements that the admixtures should meet, meaning that there was no standardised technological control of cement-based composites with admixtures at that time.

In 2019, the NBR 11768 was completely remodelled. It was split into three parts, where Part 1 refers to the classification and requirements, and Part 2 and 3 aggregate the specific tests for the various admixtures. While the 1992 standard classified the admixtures in 9 different types, and the 2011 version, 11 types, the 2019 standard brought 16 classifications ( 9 of them entirely new). Table 8 summarises the main differences observed throughout the years (note: the specified requirements are non-exclusive - only the most relevant ones were shown).

Table 8. Evolution of concrete admixture standards in Brazil and their main requirements

\begin{tabular}{|c|c|c|c|c|c|}
\hline \multicolumn{2}{|r|}{1992 (4 pages) } & \multicolumn{2}{|r|}{2011 (25 pages) } & \multicolumn{2}{|r|}{2019 (33 pages) } \\
\hline Type & Description $^{1}$ & Type & Description $^{2}$ & Type & Description $^{4}$ \\
\hline \multirow{3}{*}{$\mathrm{P}$} & Plasticiser & \multirow{3}{*}{$\mathrm{PN}$} & Water-reducing/Plasticiser & \multirow{3}{*}{ RA1 } & Water-reducing type 1 \\
\hline & $\begin{array}{l}\text { Minimum } 6 \% \text { water } \\
\text { reduction }{ }^{3} \text {. }\end{array}$ & & - Minimum $6 \%$ water reduction ${ }^{3}$. & & - Minimum 8\% water reduction ${ }^{3}$. \\
\hline & $\begin{array}{l}\text { No references to chemical } \\
\text { composition. }\end{array}$ & & $\begin{array}{l}\text { First-generation plasticizer, based } \\
\text { on lignosulfonates. }\end{array}$ & & $\begin{array}{l}\text { No references to chemical } \\
\text { composition. }\end{array}$ \\
\hline \multirow{6}{*}{ SP } & Superplasticiser & \multirow{3}{*}{ SP-I N } & High-range water-reducing Type I & \multirow{6}{*}{ RA2 } & Water-reducing type 2 \\
\hline & $\begin{array}{l}\text { Minimum } 12 \% \text { water } \\
\text { reduction }{ }^{3} .\end{array}$ & & Minimum $12 \%$ water reduction ${ }^{3}$. & & $\begin{array}{l}\text { Minimum } 15 \% \text { water } \\
\text { reduction }{ }^{3} \text {. }\end{array}$ \\
\hline & $\begin{array}{l}\text { No references to chemical } \\
\text { composition. }\end{array}$ & & $\begin{array}{l}\text { Second-generation } \\
\text { superplasticizer, based on condensates } \\
\text { of formaldehyde sulfonates. }\end{array}$ & & $\begin{array}{l}\text { No references to chemical } \\
\text { composition. }\end{array}$ \\
\hline & & \multirow{3}{*}{ SP-II N } & High-range water-reducing Tipo II & & \\
\hline & & & - Minimum 20\% water reduction ${ }^{3}$. & & \\
\hline & & & $\begin{array}{l}\text { Third generation superplasticizer, } \\
\text { based on polycarboxylate. }\end{array}$ & & \\
\hline \multirow{3}{*}{ A } & $\begin{array}{l}\text { Set Accelerating and Strength } \\
\text { accelerator }\end{array}$ & \multirow{3}{*}{ AP } & Set Accelerating & \multirow[b]{2}{*}{ AP } & Set Accelerating \\
\hline & $\begin{array}{l}\text { - Minimum initial set time: - } \\
\qquad 1: 00 \mathrm{~h}^{3}\end{array}$ & & - Minimum initial set time: $-0: 30 \mathrm{~h}^{3}$ & & $\begin{array}{l}\text { - Setting time of test mortar must } \\
\text { be smaller than the reference mortar } \\
\text { (no value specified) }\end{array}$ \\
\hline & $\begin{array}{l}\text { Minimum final set time: - } \\
1: 00 \mathrm{~h}^{3}\end{array}$ & & $\begin{array}{l}\text { No requirements regarding } \\
\text { minimum final set time. }\end{array}$ & APP & Set Accelerating for shotcrete \\
\hline
\end{tabular}


Table 8. Continued...

\begin{tabular}{|c|c|c|c|c|c|}
\hline \multicolumn{2}{|r|}{1992 (4 pages) } & \multicolumn{2}{|r|}{2011 (25 pages) } & \multicolumn{2}{|r|}{2019 (33 pages) } \\
\hline \multirow[t]{6}{*}{ Type } & Description $^{1}$ & Type & Description $^{2}$ & Type & Description $^{4}$ \\
\hline & & & & & $\begin{array}{c}\cdot \text { Initial setting of cement paste: } \leq \\
0: 10 \mathrm{~h}^{3}\end{array}$ \\
\hline & & & & & $\begin{array}{l}\text { - Final setting of cement paste: } \leq \\
1: 00 \mathrm{~h}^{3}\end{array}$ \\
\hline & & \multirow{3}{*}{$\mathrm{AR}$} & Strength accelerator & \multirow{3}{*}{ AR } & Strength accelerator \\
\hline & & & $\begin{array}{l}\text { Minimum strength increase in } \\
24 \mathrm{~h}:+120 \%{ }^{3}\end{array}$ & & $\begin{array}{l}\text { Minimum strength increase in } \\
24 \mathrm{~h}: 120 \%^{3}\end{array}$ \\
\hline & & & $\begin{array}{l}\text { No requirements regarding setting } \\
\text { time (may or may not alter) }\end{array}$ & & $\begin{array}{c}\text { Maximum initial set time: } \\
120 \%{ }^{3}\end{array}$ \\
\hline \multirow[b]{2}{*}{$\mathrm{R}$} & Set Retarding & \multirow[b]{2}{*}{$\mathrm{RP}$} & Set Retarding & & \\
\hline & $\begin{array}{l}\text { - Minimum initial set time: }+ \\
1: 00 \mathrm{~h}^{3}\end{array}$ & & $\begin{array}{l}\text { - Minimum initial set time: }+ \\
1: 30 \mathrm{~h}^{3}\end{array}$ & & - \\
\hline \multirow{3}{*}{ PA } & Plasticiser and Set Accelerating & \multirow{3}{*}{ PA } & Water-reducing and Set Accelerating & \multirow{3}{*}{ RA1-A } & $\begin{array}{l}\text { Water-reducing type } 1 \text { and Set } \\
\text { Accelerating }\end{array}$ \\
\hline & - Combined requirements & & - Combined requirements & & - Minimum $8 \%$ water reduction ${ }^{3}$. \\
\hline & & & & & $\begin{array}{l}\text { - Minimum initial set time: - } \\
0: 30 \mathrm{~h}^{3}\end{array}$ \\
\hline \multirow{3}{*}{ SPA } & $\begin{array}{l}\text { Superplasticiser and Set } \\
\text { Accelerating }\end{array}$ & $\begin{array}{l}\text { SP-I A } \\
\text { or }\end{array}$ & $\begin{array}{l}\text { High-range water-reducing and Set } \\
\text { Accelerating }\end{array}$ & \multirow{3}{*}{ RA2-A } & $\begin{array}{l}\text { Water-reducing type } 2 \text { and Set } \\
\text { Accelerating }\end{array}$ \\
\hline & - Combined requirements & SP-II A & - Combined requirements & & $\begin{array}{l}\cdot \text { Minimum } 15 \% \text { water } \\
\text { reduction }{ }^{3} \text {. }\end{array}$ \\
\hline & & & & & $\begin{array}{l}\text { - Minimum initial set time: - } \\
0: 30 \mathrm{~h}^{3}\end{array}$ \\
\hline \multirow{3}{*}{ PR } & Plasticiser and Set Retarding & \multirow{3}{*}{ PR } & Water-reducing and Set Retarding & \multirow{3}{*}{ RA1-R } & $\begin{array}{l}\text { Water-reducing type } 1 \text { and Set } \\
\text { Retarding }\end{array}$ \\
\hline & - Combined requirements & & Combined requirements & & - Minimum $8 \%$ water reduction ${ }^{3}$. \\
\hline & & & & & $\begin{array}{l}\cdot \text { Minimum initial set time: } \\
+2: 00 \mathrm{~h}^{3}\end{array}$ \\
\hline \multirow{3}{*}{ SPR } & Superplasticiser and Set Retarding & $\begin{array}{l}\text { SP-I R } \\
\text { or }\end{array}$ & $\begin{array}{c}\text { High-range water-reducing and Set } \\
\text { Retarding }\end{array}$ & \multirow{3}{*}{ RA2-R } & $\begin{array}{l}\text { Water-reducing type } 2 \text { and Set } \\
\text { Retarding }\end{array}$ \\
\hline & - Combined requirements & SP-II R & - Combined requirements & & $\begin{array}{l}\cdot \text { Minimum } 15 \% \text { water } \\
\text { reduction }{ }^{3} \text {. }\end{array}$ \\
\hline & & & & & $\begin{array}{l}\text { Minimum initial set time: } \\
+1: 30 \mathrm{~h}^{3}\end{array}$ \\
\hline \multirow{5}{*}{ IAR } & Air-entraining & \multirow{5}{*}{ IA } & Air-entraining & \multirow{3}{*}{ IA } & Air-entraining \\
\hline & - Maximum bleeding: $2 \%$ & & $\begin{array}{l}\text { Minimum air-entrainment: } \\
+2.5 \%{ }^{3}\end{array}$ & & $\begin{array}{l}\text { Minimum air-entrainment: } \\
+2.5 \%{ }^{3}\end{array}$ \\
\hline & $\begin{array}{l}\text { No references to air entrainment } \\
\text { potential. }\end{array}$ & & Total air-entrainment content: 4 to $6 \%$ & & $\begin{array}{l}\text { Total air-entrainment content: } 4 \text { to } \\
6 \%\end{array}$ \\
\hline & & & & \multirow{2}{*}{ IA-L } & $\begin{array}{l}\text { Air-entraining for lightweight } \\
\text { concretes }\end{array}$ \\
\hline & & & & & $\cdot$ No requirements specified ${ }^{5}$ \\
\hline \multirow{3}{*}{\multicolumn{2}{|c|}{-}} & \multirow{3}{*}{\multicolumn{2}{|c|}{-}} & \multirow{3}{*}{$\mathrm{CH}$} & Hydration controller \\
\hline & & & & & $\cdot$ Slump $>10 \mathrm{~mm}^{3}$ \\
\hline & & & & & $\begin{array}{l}\cdot \text { No setting time or heat of } \\
\text { hydration requirements specified. }\end{array}$ \\
\hline \multirow{4}{*}{\multicolumn{2}{|c|}{-}} & & & \multirow{4}{*}{$\mathrm{CR}$} & Shrinkage compensating \\
\hline & & & & & Shrinkage at 28 days: $\leq 95 \%{ }^{3}$ \\
\hline & & & - & & Final setting time: $\leq 1: 30 \mathrm{~h}^{3}$ \\
\hline & & & & & $\begin{array}{l}\text { Other physical and chemical } \\
\text { requirements. }\end{array}$ \\
\hline & & & & & Shrinkage reducing \\
\hline & & & & & Shrinkage at 28 days: $\leq 95 \%{ }^{3}$ \\
\hline & - & & - & $\mathrm{RR}$ & Final setting time: $\leq 2: 00 \mathrm{~h}^{3}$ \\
\hline & & & & & $\begin{array}{l}\text { No other physical and chemical } \\
\text { requirements specified. }\end{array}$ \\
\hline
\end{tabular}


Table 8. Continued...

\begin{tabular}{|c|c|c|c|c|c|}
\hline \multicolumn{2}{|c|}{1992 (4 pages) } & \multicolumn{2}{|c|}{2011 ( 25 pages) } & \multicolumn{2}{|r|}{2019 (33 pages) } \\
\hline Type & Description $^{1}$ & Type & Description $^{2}$ & Type & Description $^{4}$ \\
\hline \multirow{2}{*}{\multicolumn{2}{|c|}{-}} & \multirow{2}{*}{\multicolumn{2}{|c|}{-}} & \multirow{2}{*}{$\mathrm{RC}$} & Corrosion-inhibiting \\
\hline & & & & & - No requirements specified ${ }^{5}$ \\
\hline \multirow{3}{*}{\multicolumn{2}{|c|}{-}} & \multirow{3}{*}{\multicolumn{2}{|c|}{-}} & \multirow{3}{*}{ MV-RT } & Water retainer viscosity modifier \\
\hline & & & & & $\cdot$ Bleeding $<15 \%$ \\
\hline & & & & & $\begin{array}{l}\text { - No workability requirements } \\
\text { specified. }\end{array}$ \\
\hline \multirow{2}{*}{\multicolumn{2}{|c|}{-}} & \multirow{2}{*}{\multicolumn{2}{|c|}{-}} & \multirow{2}{*}{ MV-AS } & Anti-washout viscosity modifier \\
\hline & & & & & $\cdot$ No requirements specified ${ }^{5}$ \\
\hline \multirow{2}{*}{\multicolumn{2}{|c|}{-}} & \multirow{2}{*}{\multicolumn{2}{|c|}{-}} & \multirow{2}{*}{$\mathrm{RAC}$} & Capillary absorption reducer \\
\hline & & & & & $\cdot$ No requirements specified ${ }^{5}$ \\
\hline \multirow{2}{*}{\multicolumn{2}{|c|}{-}} & \multirow{2}{*}{\multicolumn{2}{|c|}{-}} & \multirow{2}{*}{$\mathrm{RP}$} & Permeability reducer \\
\hline & & & & & No requirements specified ${ }^{5}$ \\
\hline \multirow{2}{*}{\multicolumn{2}{|c|}{-}} & \multirow{2}{*}{\multicolumn{2}{|c|}{-}} & \multirow[t]{2}{*}{ CVP } & $\begin{array}{l}\text { Admixtures for vibro-pressed } \\
\text { concrete }\end{array}$ \\
\hline & & & & & - No requirements specified ${ }^{5}$ \\
\hline
\end{tabular}

${ }^{1}$ In the 1992 standard, excluding air-entraining admixtures (IAR), all others, when intended for concretes without entrained air, must not incorporate an air content greater than $3 \% .{ }^{2}$ In the 2011 standard, excluding air-entraining admixtures (IA), all others, when intended for concretes without entrained air, must not incorporate an air content greater than $2 \% .{ }^{3}$ In relation to reference concrete. ${ }^{4}$ In the 2019 standard, admixtures $\mathrm{CH}, \mathrm{AR}, \mathrm{CR}$, and MV-RT were required to promote less than $2 \%$ air-entrainment in relation to reference concrete; AP, $4 \%$; and RR, $1 \%$. No air-entrainment requirements were specified for the other types. ${ }^{5}$ These admixture types were defined, but no requirements were presented regarding any property other than the general requirements for all admixtures (homogeneity, colour, density, solid content, $\mathrm{pH}$, and water-soluble chlorides).

\section{FINAL REMARKS}

The present bibliographic review made clear that there are no systematic records in the civil construction sector in Brazil, motivating the authors to develop a chronology of the standards related to cement and admixtures in the country. The National Union of the Cement Industry (SNIC) itself only published annual reports from 2001 to 2013. No national statistics were found on the sale or use of chemical admixtures. In this scenario, this work sought to contribute to the creation of a literary collection about Portland cement and chemical admixtures in Brazil.

It is undeniable that Brazil is mainly an importer of concrete-related technologies, even though its construction sector heavily relies on this material. The changes that occurred in the Brazilian types of cement over the decades, motivated mainly by industrial and urban growth, followed international trends with a certain delay. This delay, originally on the order of decades, has been gradually reducing in recent years. This reducing trend relates to the acceleration of the rate of technology transfer worldwide, a consequence of the globalisation of the economy, and was observed both concerning the adoption of new technologies and the evolution of the standards for the studied materials. Brazilian standards generally follow closely their American and British counterparts.

The literature review showed that knowledge about the evolution of Portland cement and chemical admixtures is relevant information that can assist in the dating process of Brazilian concretes. On one hand, although periodic changes in the maximum limits of the compositions do occur, manufacturers do not disclose the content of admixtures effectively employed in each cement type. Additionally, alterations in the standards and in the main components of the clinker are gradual and occur over decades. On the other hand, in specific time windows, significant changes can be identified, such as the introduction of a new type of cement or chemical admixture [39]. In this sense, the combination of the historical basis developed in the present work with microstructural characterisation techniques may lay the basis for an effective dating methodology of Brazilian concretes.

\section{ACKNOWLEDGEMENTS}

We gratefully acknowledge the agency FAPEMIG (Fundação de Amparo à Pesquisa do Estado de Minas Gerais) for providing financial support in the form of a scholarship. We are also grateful for the infrastructure and collaboration of the Research Group on Solid Wastes - RECICLOS - CNPq.

\section{REFERENCES}

[1] K. J. Beasley, "Carbon dating concrete cracks," J. Perform. Constr. Facil., vol. 29, no. 1, 02514002, 2015. 
[2] S. O. Ekolu, "A review on effects of curing, sheltering, and $\mathrm{CO}_{2}$ concentration upon natural carbonation of concrete," Constr. Build. Mater., vol. 127, pp. 306-320, 2016.

[3] S. O. Ekolu, "Model for practical prediction of natural carbonation in reinforced concrete: Part 1-formulation," Cement Concr. Compos., vol. 86, pp. 40-56, 2018.

[4] S. Park, S. Kwon, and S. H. Jung, "Analysis technique for chloride penetration in cracked concrete using equivalent diffusion and permeation," Constr. Build. Mater., vol. 29, pp. 183-192, 2012.

[5] Associação Nacional das Entidades de Produtores de Agregados para Construção, The Aggregate Market in Brazil. São Paulo: ANEPAC, 2015.

[6] J. J. Biernacki et al., "Cements in the 21st century: challenges, perspectives, and opportunities," J. Am. Ceram. Soc., vol. 100, pp. 2746-2773, 2017.

[7] R. G. Blezard, Reflections on the History of the Chemistry of Cement (SCI Lecture Papers Series). London: Soc. Chem. Ind., 1998, pp. 1-27.

[8] R. G. Blezard, “The history of calcareous cements," in Lea's Chemistry of Cement and Concrete, P. C. Hewlett, Ed., Oxford: Elsevier Sci. Technol. Books, 2004.

[9] F. Pintér and C. Gosselin, "The origin, composition and early age hydration mechanisms of Austrian," Cement Concr. Res., vol. 110, pp. 1-12, 2018.

[10] H. Taylor, Cement Chemistry, 2nd ed. London: Thomas Telford, 1997.

[11] P. K. Mehta and P. J. M. Monteiro, Concrete: Microstructure, Properties and Materials, 4th ed. New York: McGraw-Hill Education, 2014.

[12] P. Tennis and J. Bhatty, "Portland cement characteristics-2004," Concr. Technol. Today, vol. 26, pp. 1-3, 2005.

[13] Cimento \& Concreto, "Indústria do cimento nasce com a II Revolução Industrial," Cimento Concr., no. 29, pp. 1-10, 1976.

[14] A. F. Battagin and I. L. S. Battagin, "O cimento Portland no Brasil,” in G. C. Isaia, Ed., Materiais de Construção Civil e Princípios de Ciência e Engenharia de Materiais, 2a ed. São Paulo: IBRACON, 2010.

[15] Associated Portland Cement Manufacturers, Grace's Guide to British Industrial History. 2019. Accessed: June 18, 2020. [Online]. Available: https://www.gracesguide.co.uk/Associated_Portland_Cement_Manufacturers

[16] PCA. "PCA (America’s Cement Manufacturers)." cement.org (accessed June 18, 2019).

[17] Sindicato Nacional da Indústria do Cimento. http://snic.org.br/assets/pdf/numeros/1588788177.pdf (accessed June 18, 2019).

[18] Global Cement Magazine, Global Cement Top 100 Report 2017-2018. 2017. Accessed: June 18, 2020. [Online]. Available: https://www.globalcement.com/magazine/articles/1054-global-cement-top-100-report-2017-2018

[19] Brazilian Portland Cement Association, 70 Years - a Success Story (in portuguese). São Paulo: ABCP, 2006.

[20] P. K. Mehta, Cement Standards, Evolution and Trends: a Symposium Sponsored by ASTM Committee C-1 on Cement, American Society for Testing and Materials, St. Louis, Mo., 7 Dec. 1977. Philadelphia: American Society for Testing and Materials, 1978.

[21] J. M. Illston and P. Domone, Construction Materials: Their Nature and Behaviour, 3rd ed. CRC Press, 2001.

[22] H. Gonnerman and W. Lerch, "Changes in characteristics of portland cement as exhibited by laboratory tests over the period 1904 to 1950," in Changes in Characteristics of Portland Cement as Exhibited by Laboratory Tests Over the Period 1904 to $1950, \mathrm{H}$. Gonnerman and W. Lerch, Eds., West Conshohocken: ASTM Internacional, 1952.

[23] B. Raath and J. Horton, "Is faster and faster, better and better," in Proc. Conf. Concr. 21st Century: Modern Concr. Prog. through Innov.: Concr. Soc. Southern Africa, 2001, pp. 13-14.

[24] P. K. Mehta and R. W. Burrows, "Building durable structures in the 21st century," ACI Concr. Int., vol. 23, pp. 57-63, 2001.

[25] E. Gartner, "Industrially interesting approaches to "low-CO2" cements," Cement Concr. Res., vol. 34, no. 9, pp. 1489-1498, 2004.

[26] S. O. Ogbeide, "Developing an optimization model for $\mathrm{CO}_{2}$ reduction in cement production process," J. Eng. Sci. Technol., vol. 3, no. 1, pp. 85-88, 2010.

[27] K. Yang, Y. Jung, M. Cho, and S. Tae, "Effect of supplementary cementitious materials on reduction of $\mathrm{CO}_{2}$ emissions from concrete," J. Clean. Prod., vol. 103, pp. 774-783, 2015.

[28] A. F. Battagin "Cimento Portland," in Concreto: Ciência e Tecnologia, 1a ed., G. C. Isaia, Ed., São Paulo: IBRACON, 2011.

[29] I. N. Grubeša, I. Barisic, A. Fucic, and S. S. Bansode, Characteristics and Uses of Steel Slag in Building Construction, 1 st ed. Amsterdam: Woodhead Publishing, 2016.

[30] Associação Brasileira de Normas Técnicas, Portland Cement - Requirements, NBR 16697, 2018.

[31] ASTM International, 20 Standard Specification for Portland Cement, ASTM C150/C150M, 2020.

[32] ASTM International, 20 Standard Specification for Blended Hydraulic Cements, ASTM C595/C595M, 2020.

[33] BSI Group, Cement - Composition, Specifications and Conformity Criteria for Common Cements, BS EN 197-1:2011, 2011. 
[34] Instituto Brasileiro de Geografia e Estatistica, Anuário Estatístico do Brasil, 2020. [Online]. Available: https://biblioteca.ibge.gov.br/biblioteca-catalogo?id=720\&view=detalhes

[35] Associação Brasileira de Cimento Portland, Guia Básico de Utilização do Cimento Portland, 7a ed. São Paulo: ABCP, 2002.

[36] B. J. Ruijven, D. P. Vuuren, W. Boskaljon, M. Neelis, D. Saygin, and M. K. Patel, "Long-term model-based projections of energy use and CO2 emissions from the global steel and cement industries," Resour. Conserv. Recycling, vol. 112, pp. 15-36, 2018.

[37] Q. Wang, P. Yan, and G. Mi, "Effect of blended steel slag-GBFS mineral admixture on hydration and strength of cement," Constr. Build. Mater., vol. 35, pp. 8-14, 2012.

[38] S. Z. Carvalho, F. Vernilli, B. Almeida, M. Demarco, and S. N. Silva, "The recycling effect of BOF slag in the portland cement properties," Resour. Conserv. Recycling, vol. 127, pp. 216-220, 2017.

[39] A. F. Battagin and S. L. Centurione, "Panorama do uso do gesso na indústria brasileira de cimento," in An. 33 Cong. Bras. Cerâm., São Paulo, 1989.

[40] Instituto Aço Brasil, Relatório de Sustentabilidade 2016-2017. Rio de Janeiro: IABR, 2018.

[41] E. Belhadj, C. Diliberto, and A. Lecomte, "Characterization and activation of basic oxygen furnace slag," Cement Concr. Compos., vol. 34, no. 1, pp. 34-40, 2012.

[42] CSN. "Cimento." http://www.csn.com.br/conteudo_pti.asp?idioma=0\&conta=45\&tipo=59653. (accessed June 18, 2020].

[43] M. Schneider, M. Romer, M. Tschudin, and H. Bolio, "Sustainable cement production--present and future," Cement Concr. Res., vol. 41, no. 7, pp. 642-650, 2011.

[44] L. Mlinárik and K. Kopecskó, "Impact of metakaolin - a new supplementary material - on the hydration mechanism of cements," Acta Tech. Napocensis Civ. Eng. Archit., vol. 56, no. 2, pp. 100-110, 2013.

[45] H. El-Diadamony, A. Amer, T. M. Sokkary, and S. El-Hoseny, "Hydration and characteristics of metakaolin pozzolanic cement pastes," HBRC J., vol. 14, no. 2, pp. 150-158, 2018.

[46] A. Ramezanianpour, E. Ghiasvand, I. Nickseresht, M. Mahdikhani, and F. Moodi, "Influence of various amounts of limestone powder on performance of Portland limestone cement concretes," Cement Concr. Compos., vol. 31, pp. 715-720, 2009.

[47] P. Thongsanitgarn, W. Wongkeo, A. Chaipanich, and C. S. Poon, "Heat of hydration of Portland high-calcium fly ash cement incorporating limestone powder: Effect of limestone particle size," Constr. Build. Mater., vol. 66, no. 15, pp. 410-417, 2014.

[48] V. Bonavetti, H. Donza, V. Rahhal, and E. Irassar, "Influence of initial curing on the properties of concrete containing limestone blended cement," Cement Concr. Res., vol. 30, pp. 703-708, 2000.

[49] R. Faria, "Solução fluída," Rev. Téchne, vol. 132, 2008.

Author contributions: JFN: data curation, formal analysis, methodology, writing; ECT: data curation, formal analysis; JCM: data curation, writing, methodology; RAFP: supervision, writing.

Editors: Fernando Pelisser, Guilherme Aris Parsekian. 


\section{APPENDIX}

The sources for the chemical composition shown in Figure 2 are the following:

- Abrams, D. A., 1919. Design of Concrete Mixtures - Bulletin 1. Chicago: Structural Materials Research Laboratory, Lewis Institute.

- Abrams, D. A., 1919. Effect of vibration, jigging and pressure on fresh concrete - Bulletin 3. Chicago: Structural Materials Research Laboratory, Lewis Institute.

- Abrams, D. A., 1922. Flexural Strength of Plain Concrete - Bulletin. Chicago: Structural Materials Research Laboratory.

- Abrams, D. A., 1925. Quantities of materials for concrete - Bulletin. 2 ed. Chicago: Structural Materials Research Laboratory.

- Adriolo, F. R., 1984. Construções de Concreto - Manual de Práticas para controle e Execução. s.l.:PINI.

- Aïtcin, P., 2008. Binders for Durable and Sustainable Concrete - Modern Concrete Technology. s.1.:Taylor \& Francis.

- Aïtcin, P., Mindess, S. \& Tagnit-Hamou, A., 2012. Building Highly Sustainable Concrete (HSC) Structures Symposium STOCKHOLM. Concrete Structures for Sustainable Community - KTH Royal Institute of Technology.

- ASTM, 1904. Report of Committee on Standard Specifications for Cements. s.l.:American Society for Testing Materials.

- ASTM, 1994. C150/C150M-20: Standard Specification for Portland Cement, s.l.: American Society for Testing Materials.

- Bauer, L. A. F., 1995. Materiais de Construção. 5 ed. Rio de Janeiro: LTC.

- Benedix, R., 2005. Bauchemie - Einführung in die Chemie für Bauingenieure. 3 ed. s.1.:Teubner.

- Bensted, J. \& Barnes, P., 2002. Structure and Performance of Cements. 2 ed. s.l.:Spon Press.

- Bentz, D. P., 1997. Three-Dimensional Computer Simulation of Portland Cement Hydration and Microstructure Development. Journal of the American Ceramic Society, 80(1), pp. 3-21.

- Bhatty, I. \& Tennis, P. D., 2008. U.S. and Canadian Cement Characteristics: 2004. s.1.:Portland Cement Association, Research \& Development Information.

- Blount, B., 1912. Lectures on Cements. s.l.:The Institute of Chemistry of Great Britain and Ireland .

- Boateng, A., 2008. Rotary Kilns - Transport Phenomena and Transport Processes. s.1.:Butterworth-Heinemann Elsevier.

- Bogue, R. H., 1947. The Chemistry of Porland Cement. s.l.:Reinhold Book Corporation.

- Bogue, R. H. \& Herman, R., 1955. The chemistry of Portland Cement. 2 ed. s.1.:Reinhold Publishing Corporation.

- Brown, W. L., 1899. Elasticity of Portland Cement. London.

- Butler, D. B., 1899. Portland Cement, its Manufacture, testing and use. London: E\&F.N.Spon.

- Bye, G. C., 1999. Portland Cement - Composition, Production and Properties. 2 ed. s.l.:Thomas Telford.

- Carneiro, F. L. L. B., 1953. Dosagem de Concretos. 2 ed. Rio de Janeiro: INT.

- Chamecki, S., 1956. Curso de Estática das Construções. Rio de Janeiro: Editora Científica.

- Cummings, U., 1898. American Cements. Boston: Rogers \& Manson.

- Da Silva, G. R., 1975. Manual de Traços de Concreto. 3 ed. São Paulo: Livraria Nobel S.A..

- Darwin, D., Young, J. F. \& Mindess, S. F., 2003. Concrete. 2 ed. s.1.:Prentice Hall.

- Duda, W. H., 1984. Cement Data Book,Volume 2: Automation, Storage, Transportation, Dispatch. s.l.:French \& European Pubns.

- Duda, W. H., 1985. Cement Data Book, Volume One: International Process Engineering in the Cement Industry. 3 ed. s.l.: French \& European Pubns.

- Duda, W. H., 1988. Cement Data Book, Volume 3: Raw Material for Cement Production. s.1.:French \& European Pubns.

- Duda, W. H., 2003. Cemento, Manual Tecnológico. s.l.:Editorial Reverté.

- Eisenmann, J., Leykauf, G. \& Kupfer, H., 2003. Beton-fahrbahnen. s.1.:Ernst\&Sohn.

- Falk, M. S., 1904. Cements, Mortars and Concretes - Their Physical Properties. New York: M.C. Clark.

- Federal Highway Administration - USA - Publication No. HIF -07-004, 2009. Integrated Materials and Construction Practices for Concrete Pavement. s.l.:A State of the Practice Manual.

- Fritz, K., 1971. Zement - Herstellung und Eigenschaften. s.l.:Springer-Verlag.

- Frohnsdorff, G. et al., 1997. Guide to the Selection of Hydraulic Cements, s.l.: ACI Committee 225.

- Furnas, E. d., 1997. Concretos massa, estrutural, projetado e compactado com rolo: ensaios e propriedades. São Paulo: PINI/Walton Pacelli de Andrade. 
- Gatehouse, F. B., 1908. A Handbook for Cement Works Chemists. London: HardPress Publishing.

- Glasser, F. P., 2005. Thermodynamics of Cement Hydration. Em: F. Young \& J. P. Skalny, eds. Materials Science of Concrete VII. s.l.:The American Ceramic.

- Graf, O., 1950. Die Baustoffe, Ihre Eigenschaften und ihre Beurteilung. Stuttgart: Konrad Wittwer.

- Helene, P., 2003. Por que trabalhar com concretos de resistências mais elevadas que as atuais?. Campinas: SindusCon/SP.

- Helene, P. \& Terzian, P., 1992. Manual de Dosagem e Controle do Concreto. Brasília: PINI.

- Hewlett, P. C., 1998. Lea's Chemistry of Cement and Concrete. 14 ed. s.l.:John Wiley \& Sons.

- Hooton, R. D., Boyd, A. J. \& Bhadkamka, D. D., 2005. Effect of Cement Fineness and C3S Content on Properties of Concrete: A literature Review. PCA R\&D Series, pp. 2-11.

- Johansen, V. C., Taylor, P. C. \& Tennis, P. D., 2006. Effect of Cement Characteristics on Concrete Properties. s.1.:Portland Cement Association, Engineering Bulletin 226.

- Johansen, V. \& Kouznetzova, T. V., 1992. Clinker formation and new processes. 9th International Congress on the Chemistry of Cement, Volume 1, pp. 49-79.

- Kleinlogel, A., Hundeshagen, F. \& Graff, O., 1930. Einflüsse auf Beton. s.1.:Wilhelm Ernst \& Sohn.

- Kosmatka, S. H., Kerkhoff, B. \& Panarese, W. C., 2005. Design and Control of Concrete Mixtures. 14 ed. s.1.:Portland Cement Association.

- Lea, F. M., 1935. The chemistry of Cement and Concrete. 1 ed. New York: Chemical Publishing Company.

- Lea, F. M., 1970. The chemistry of Cement and Concrete. 3 ed. New York: Chemical Publishing Company.

- Lin, L. et al., 2004. Development and Research of High Belite Cement Dam Concrete with low heat and high crack resistance. International Workshop on Sustainable Development and Concrete Technology.

- Locher, F. W., 2005. Cement - Principles of Production and Use. s.1.:Bau+Technik.

- Maekawa, K., Ishida, T. \& Kishi, T., 2009. Multi-Scale Modeling of Structural Concrete. s.1.:Taylor \& Francis.

- Meade, R. K., 1901. Portland Cement - Chemical and Physical Examination. Easton: The Chemical Publishing Company .

- Meade, R. K., 1909. Portland Cement - Its Composition, Raw Materials Manufacture, Testing and Analysis. Easton: The Chemical Publishing Company.

- Mehta, P. K., 1999. Concrete Technology for Sustainable Development. ACI - Concrete International, 21(11), pp. 47-53.

- Mehta, P. K. \& Burrows, R. W., 2001. Building durable structures in the 21 st century. ACI Concrete Internacional, Volume 23, pp. 57-63.

- Neville, A., 1994. Cement and Concrete: Their Interrelation in Practice - Advances in Cement and Concrete. s.1.:American Society of Civil Engineers.

- Neville, A., 2006. Neville on Concrete - An Examination of issues in Concrete Practice. 2 ed. s.1.:Booksurge LLC.

- Neville, A. M., 1985. Properties of Concrete. s.l.:Addison Wesley.

- Neville, A. M., 1994. Cement and Concrete: Their Interrelation in Practice - Advances in Cement and Concrete. s.1.:American Society of Civil Engineers.

- Newberry, S. B., 1899. How to use Portland Cement. Chicago: Forgotten Books.

- Odler, I., 2000. Special Inorganic Cements - Modern Concrete Technology. London: E\&FN SPON.

- Peray, K. E., 1986. Rotary Cement Kiln. 2 ed. s.1.:CHS Press.

- Petrucci, E. G., 1968. Concreto de Cimento Portland. s.l.:Associação Brasileira de Cimento Portland.

- Pizarro, R. A., 1964. Concreto: Cimentos, Agregados - Dosagem e Propriedades. Escola Nacional de Engenharia, Universidade do Brasil.

- Poole, A. et al., 1998. Concrete Petrography - A handbook of investigative techniques. 5 ed. New York: Arnold John Wiley.

- Ramachandran, V. S. \& Beaudoin, J., 2001. Handbook of Analytical Techniques in Concrete Science and Technology. New Jersey: Noyes Publications.

- Redgrave, G. R., 1895. Calcareous Cements: Their Nature And Uses With Some Observations Upon Cement Testing. London: Forgotten Books.

- Reid, H., 1869. A practical treatise on concrete and how to make it: with observations on the uses of cements, lime and mortars. London: E.\& F. SPON.

- Reid, H., 1877. The Science and Art of the Manufacture of Portland Cement. London: E.\& F.N. SPON.

- Sabin, L. C., 1905. Cement and Concrete. New York: McGRAW Publishing Company. 
- Skalny, J., Gebauer, J. \& Odler, I., 2001. Calcium Hydroxide in Concrete - Materials science of Concrete. s.l.:American Ceramic Society/SA.

- Spalding, F. P., 1898. Hydraulic Cement - Its Properties, Testing and Use. New York: John Wiley \& Sons.

- Srinivasan, D., 2008. Guide for Good Concrete Construction. s.1.:Indian Concrete Institute.

- Stark, J. \& Wicht, B., 2000. Zement und Kalk-Der Baustoff als Werkstoff. s.1.:F. A. Finger.

- Stark, J. \& Wicht, B., 2001. Dauerhaftigkeit von Beton - Der Baustoff als Werkstoff. s.l.:F. A. Finger.

- Sui, T. et al., 2004. Study on the Properties of High Strength Concrete using High Belite Cement. Journal of Advanced Concrete Technology, 2(2), pp. 201-208.

- Sui, T. et al., 2006. A Comparison of HBC \& MHC Massive Concretes for Three Gorges Project in China. Em: M. S. Konsta-Gdoutos, ed. Measuring, Monitoring and Modeling Concrete Properties: An International Symposium dedicated to Professor Surendra P. Shah. 1 ed. s.l.:Springer.

- Taylor, H. F., 1997. Cement Chemistry. 2 ed. s.l.:Thomas Telford.

- Torres, A. F. \& Rosman, C. E., 1956. Método para dosagem racional do concreto, São Paulo: ABCP.

- Young, F. \& Skalny, J., 2005. Materials Science of Concrete VII. s.l.:American Ceramic Society.

- ZTV Beton-StB 07, 2007. Zusätzliche Technische Vertragsbedingungen und Richtlinien für den Bau von Tragschichten mit hydraulischen Bindemitteln und Fahrbahndecken aus Beton. s.l.:FGSV. 